\title{
Mycoses and Antifungals: reviewing the basis of a current problem that still is a biotechnological target for marine products
}

\section{Luciana Terra ${ }^{1}$, Paula A. Abreu ${ }^{2}$, Valéria L. Teixeira ${ }^{1 *}$, Izabel C. P. Paixão ${ }^{1}$, Rebeca Pereira ${ }^{1}$, Bruno Leal ${ }^{3}$, André Luiz Lourenço ${ }^{3}$, Pabulo H. Rampelotto ${ }^{4 *}$ and Helena C. Castro ${ }^{1 *}$}

1 PPBI - Instituto de Biologia, Universidade Federal Fluminense, Niterói, Brazil

${ }^{2}$ Faculdade de Farmácia, Universidade Federal do Rio de Janeiro, Rio de Janeiro, Brazil

${ }^{3}$ Programa de Pós-graduação de Patologia, Hospital Universitário Antonio Pedro, Universidade Federal Fluminense, Niterói, Brazil

${ }^{4}$ Interdisciplinary Center for Biotechnology Research, Federal University of Pampa, São Gabriel, Brazil

Edited by:

Donatella De Pascale, National

Research Council- CNR, Italy

Reviewed by:

Sandra Pucciarelli, University of

Camerino, Italy

Giovanna Cristina Varese, University

of Turin, Italy

\section{*Correspondence}

Valéria L. Teixeira, Pabulo $\mathrm{H}$.

Rampelotto and Helena C. Castro,

Laboratório de Antibióticos,

Bioquímica, Ensino e Modelagem

Molecular- LABiEMol, Instituto

Biologia/UFF Outeiro de São João

Batista, s/n, Campus do

Valonguinho, Niterói, $R J$

24210130, Brazil

e-mail: valerialaneuville@gmail.com;

pabulo@lacesm.ufsm.br;

hcastrorangel@yahoo.com.br
Currently, the limited number of antifungals available for treating fungal infections, the increased multiresistance, and the adverse effects are the major obstacles for fungal infection therapy. Additionally, the recent emergence of opportunistic fungus infections reinforced the requirement for discovering novel antifungal agents. Herein we reviewed the main topics about fungi and its related infections, the antifungals available, their mechanism of action and resistance profile. In this work, we pointed fungi as a biotechnological target for finding new options in alternative sources such as marine products with new mechanisms of action to allow treating these dangerous infections.

Keywords: marine products, antifungal, infection, fungi, applied mycology

\section{INTRODUCTION}

In the early twentieth century, bacterial epidemics were a major cause of mortality worldwide. In contrast, fungal infections were hardly taken into consideration. However, since the 1960s, when the use of antibiotic therapies has been established, a drastic increase of fungal infections was observed. Now, emerging fungal pathogens have been described causing severe infections, which include yeasts as azole-resistant Candida albicans and non-albicans species, Trichosporon species and filamentous fungi such as species of the genus Fusarium and of the class Zygomycetes, and some representatives of the dematiaceous molds. Literature also reported the medical importance of endemic dimorphic fungi such as Penicillium marneffei, Coccidioides immitis, Paracoccidioides brasiliensis (Marques, 2012), and Histoplasma capsulatum. Therefore, fungal infections are seen as an important threat to global health that needs to get proper attention (Vandeputte et al., 2012; Gauthier and Keller, 2013). For that purpose, molecules with a new mechanism of action and able to escape from the current fungi mechanism of resistance against antifungals are of interest.

The sea is a reservoir of a variety of organisms (bacteria, microalgae, seaweeds, invertebrate, and vertebrate animals), which are source of novel and bioactive molecules (Devi et al., 2011) (Figure 1). Marine substances presented antifungal activity against pathogenic fungi and were isolated from sea cucumber (Kumar et al., 2007), marine sponges (Piao et al., 2013), seaweeds (Guedes et al., 2012), microalgae (Kumar et al., 2013), bacteria (Petatán-Sagahón et al., 2011), mollusks and echinoderm (Umayaparvathi et al., 2012), and fishes (Hellio et al., 2012), namely, in all marine phyla (Figure 1). Unfortunately, many studies were performed with extracts of marine organisms, without the isolation of the molecules responsible for activity against fungi.

Some important reviews on biological activities of marine products have demonstrated that the antifungal activity is one of the least investigated (Mayer and Lehmann, 2000; Mayer and Hamann, 2002, 2004; Mayer and Hamannm, 2005; Mayer et al., 2007, 2009, 2011, 2013).

In this work, our purpose is to briefly review and discuss the most important fungal infections and antifungals used in the treatment and new possibilities focused on the biotechnological marine products to contribute to the treatment of these microorganism infections that compromises human health. For that purpose, we used the keywords: marine products, fungal infections, antifungals, treatment, biotechnological products in the MEDLINE, PubMed, Embase, and Cochrane databases. 


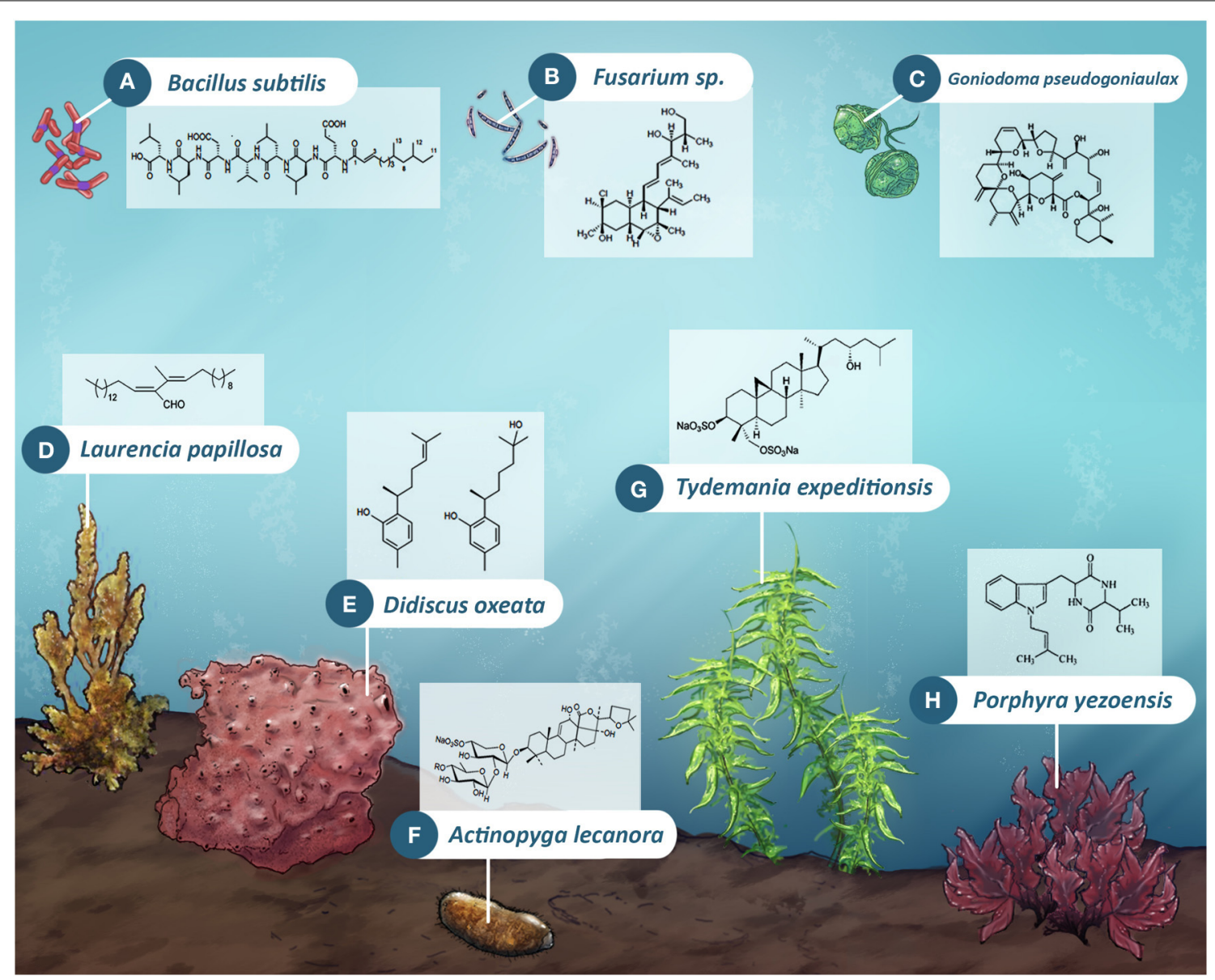

FIGURE 1 | Natural products from marine organisms with significant activity against fungal strains of health and economic relevance.

They can be found in marine-derived bacteria (A-Gageosatins $C$, a linear lipopeptide), fungi (B-Fusarielin $\mathrm{E}$, a fusaricidin derivative), dinoflagellates (C-Goniodomin A, a polyether macrolide compound), red alga (D-Aldehyde derivative (E)-2-\{(E) tridec-2-en-2-yl\} heptadec-2-enal), sponge (E-Curcuphenol and Curcudiol), sea cucumbers (F-Holothurin B, a triterpenic glycoside), macroalga (G-Cycloartan-3,23,29-triol 3,29-disodium sulfate; a sulfate-conjugated Triterpenoid) and fungal strains within other species ( $\mathrm{H}$-diketopiperazine derivative produced by fungal $\mathrm{M}-3$ strains within phylum Ascomycota, isolated from marine red algae Porphyra yezoensis) among others.

\section{FUNGUS: OVERALL LOOK IN THE MAIN TOPIC}

Most fungi do not cause problems in healthy individuals, but they can cause diseases in immunocompromised individuals. The most common opportunistic infections are caused by C. albicans and Aspergillus spp. In the recent years other fungi emerged as important infections agents, including yeast species such as non-albicans Candida species, Cryptococcus sp., Trichosporon spp., and Rhodotorula spp. and filamentous fungi such as Fusarium spp., Rhizopus spp., Rhizomucor spp., and phaeohyphomycosis agents (Sun et al., 2012; Juyal et al., 2013; Kim et al., 2013; Muhammed et al., 2013; Jain et al., 2014; Schieffelin et al., 2014).

Opportunistic mycoses have increased in the last decades, especially since 1980, due to the increase of immunocompromised patients. The predisposing factors for fungal infections include neutropenia, transplant (bone marrow or solid organ), diabetics, malignancies, malnutrition, hematological diseases and HIV. An important and major risk factor for fungal infections is the use of broad spectrum antibiotics that reduces the number of bacteria from microbiota and allows fungal growth leading to opportunistic infections. The use of devices (e.g., central venous catheters) that breaks the host-defense barriers also allows access of these agents. Thus, the use of invasive procedures and aggressive treatment (e.g., intensive care units) not only increased the survival of patients with life threatening diseases but also the number of people at risk of fungal infections (Bouza and Munoz, 2008). Finally, changes in antineoplasic chemotherapy and radiotherapy have caused profound immunosuppression and consequently an increase in the occurrence of fungal infections. These risk factors have changed the spectrum of pathogens that cause systemic infection, in favor of multiresistant fungi that severely restrict the treatment options (Harris, 2002; Richardson, 2005; Ostrosky-Zeichner et al., 2010).

\section{LIFE-THREATENING FUNGAL INFECTIONS}

Candida albicans is the major fungal pathogen of clinical importance causing high mortality in populations at risk, especially in immunocompromised patients, neutropenia, antibiotic use and prolonged periods in the intensive care unit predispose 
individuals to invasive candidiasis (Calderone and Fonzi, 2001; Wisplinghoff, 2004; Cheng et al., 2012). This microorganism is usually a commensal of the oral cavity and gastrointestinal tract of healthy humans, but can cause serious disease (Diaz et al., 2012).

Candida species are classified as the fourth leading cause of bloodstream infections in hospitals, causing a high mortality (35-45\%) according to epidemiological studies (Wisplinghoff, 2004; Drgona et al., 2014). In addition, non-albicans Candida species are now also associated with pertinent infections such as C. glabrata, C. krusei, C. parapsilosis and C. tropicalis, C. dubliniensis, have also emerged as causative agents of infections (Jordán et al., 2014). The high prevalence of non-albicans species in disease might also be a consequence of their inherently higher level of resistance to certain antifungal drugs (Silva et al., 2012).

The genus Aspergillus has about 180 species and some of them are highlighted by their clinical importance in causing human diseases (Mabey et al., 2004). These microorganisms are opportunistic pathogens and cause infection in severely debilitated individual. Inhalation of spores is the most common route of transmission and several reports described it as an agent of secondary infection in patients with debilitating diseases such as carcinoma, tuberculosis, and lesions of subcutaneous tissues, skin or cornea, neutropenic patients or in prolonged treatment with antibiotics and corticosteroids (Zmeili and Soubani, 2007).

Aspergillus can also invade the human system through the respiratory tract, severely damaged skin, trauma or surgical wounds, corneal, ear or significantly affected organ. Usually the infection is the initial process, which can be localized or spread, producing a widespread disease with involvement of more than one organ (Kousha et al., 2011). Among Aspergillus species, Aspergillus fumigatus represents $70 \%$ of clinical isolates of medical importance, whereas Aspergillus flavus, Aspergillus niger and Aspergillus terreus represent 15\%, 7\%, and 5\% respectively (Ascioglu et al., 2002).

Cryptococcosis is an opportunistic infection caused by fungi belonging to the genus Cryptococcus sp. There are over 30 different species, but Cryptococcus neoformans and Cryptococcus gattii are responsible for almost all cases of cryptococcosis in humans and animals. Infections can occur in both immunocompromised and immunocompetent hosts (Bovers et al., 2008). Cryptococcal meningitis is the main clinical manifestation and is associated with high mortality (Quian et al., 2012).

Fusarium spp. are important infectious filamentous fungi, it is particularly important among immunocompromised and neutropenic patients and is typically invasive and disseminated. Infection occurs mainly through inhalation of airborne conidia or via breaks in the skin due to trauma and/or burns (Muhammed et al., 2011). Twelve species were associated with infection; Fusarium solani was the most frequent ( $\sim 50 \%$ of cases), followed by Fusarium oxysporum ( 20\%) and Fusarium verticillioidis and Fusarium moniliforme ( $\sim 10 \%$ each) (Nucci et al., 2013).

The mycoses encompassed in the hyalohyphomycosis group are very heterogeneous, with only the presence of hyaline hyphae in tissues as a common characteristic. The number of organisms implicated in hyalohyphomycosis is increasing and the most clinically important species belong to the genera Fusarium, Scedosporium, Acremonium, Scopulariopsis, Purpureocillium, and Paecilomyces (Tortorano et al., 2014).
Zygomycosis, also known as mucormycosis, has emerged as an increasingly important pathogen during the past decade. Mucormycosis is a life-threatening invasive fungal infection that arises among immunocompromised patients, and the rhinoorbito-cerebral presentation is the most common clinical form of the disease (Teixeira et al., 2013). As failure rates are elevated with commercial antifungals, new treatment options are needed (Waness et al., 2009).

\section{CURRENT ANTIFUNGALS BIOLOGICAL FEATURES}

Currently the treatment of fungal infections is still complex, as fungi are eukaryotic organisms with similar structure and metabolism with the host cell. This feature is often responsible for the toxicity of these compounds (Sathiamoorthy et al., 2006).

Despite extensive research devoted to the development of new therapeutic strategies, there are only a limited number of drugs available for the treatment of invasive fungal infections (Figure 2 and Table 1). In fact, only four molecular classes that target three different fungal metabolic pathways are commonly used in clinical practice to treat systemic fungal infections such as fluoropyrimidine analogs, polyenes, azoles and the echinocandins (Vandeputte et al., 2012) (Table 1).

\section{5-Fluoropyrimidine}

5-fluorocytosine (5-FC) is a fluorinated derivative of cytosine. It is a prodrug and its fungistatic activity is dependent on its conversion to 5 -fluorouracil (5-FU). 5-FC rapidly enters into the fungus cytoplasm through specific transporters such as cytosine permeases and pyrimidine transporters before being converted to 5-FU by the cytosine deaminase (Hope et al., 2004). Resistance may emerge during therapy due to the decrease of the concentration of the enzyme involved in the conversion of 5-flucytosine (1) to 5FdUMP, or to the increase of cytosine synthesis (Vermes et al., 2000) (Figure 2 and Table 1).

\section{Polyenes}

More than 200 molecules that belong to this chemical class present an antifungal activity. However, only three are used in clinical medicine. Amphotericin is a polienic molecule that may be fungicidal or fungistatic depending on the dose used (Ellis, 2002). It remains for over 40 years as the first-line drug in the treatment of invasive fungal infections due to their broad spectrum of activity and low occurrence of innate or acquired resistance (Ellis, 2002; Adler-Moore and Proffitt, 2008). Meanwhile Natamycin and nystatin (2) are polienic drugs effective against fungi of the genus Cryptococcus, Candida, Aspergillus and Fusarium (Zotchev, 2003) (Figure 2 and Table 1).

\section{Azoles}

The antifungal azoles include two classes: imidazoles (first generation) and triazoles (Second generation) (Zonios and Bennet, 2008) (Figure 2 and Table 1 ). The therapeutic target of azoles is the lanosterol 14- $\alpha$-demethylase (CYP51) and its heme group (Figure 3). The inhibition of CYP51 leads to depletion of ergosterol, the main steroid present in fungal membrane, and accumulation of squalene or other toxic intermediaries in the cell, changing the membrane permeability and the fungal viability 


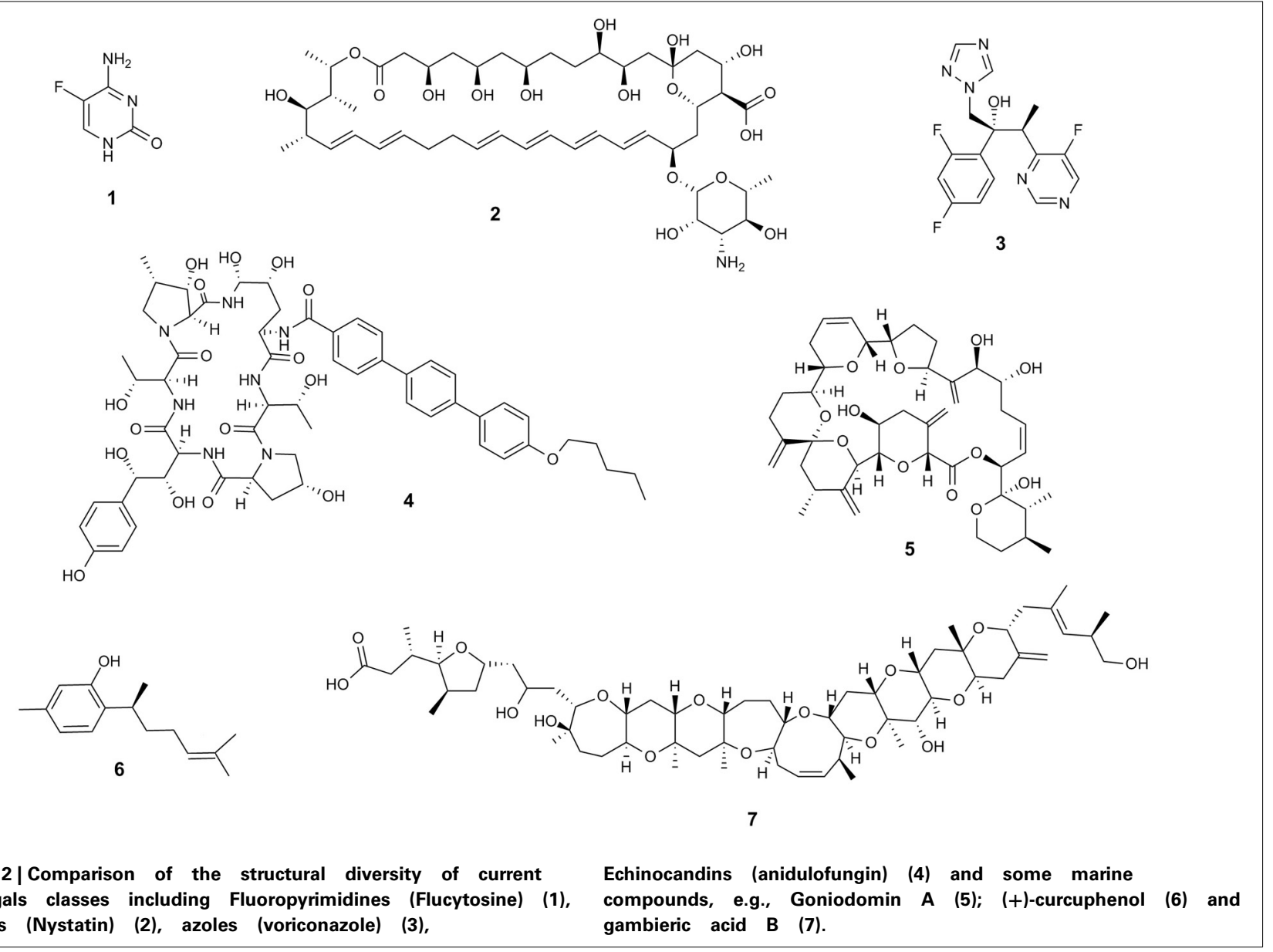

(Ascioglu et al., 2002; Bovers et al., 2008; Strushkevich et al., 2010).

All triazoles show oral activity and voriconazole (3) (Figure 2) may be administered also intravenously (Tkackz and Didomenico, 2001). New triazoles (e.g., voriconazole, posaconazole, and ravuconazole) have greater potency and broader spectrum of action. Among the three azole drugs, voriconazole was approved for clinical use by the FDA in the United States as well as posaconazole in oral suspension form for the prophylactic use including of invasive aspergillosis in immune compromised patients. Itraconazole also presents in vitro activity against amphotericin B resistant Aspergillus species and other filamentous fungi with a safety profile (Scott and Simpson, 2007).

\section{Echinocandins}

The echinocandins are synthetically modified lipopeptides naturally produced by some species of fungi such as Aspergillus rugulovalvus (caspofungin B), Zalerion arboricola (pneumocandin) and Papularias phaerosperma (papulacandin) (Denning, 2002).

Some of these antifungals (e.g., Caspofungin) act on enzymes that synthesize the fungal cell wall, which is composed of several polysaccharides such as beta $(1,3)$-glucan, beta $(1,6)$-glucan, and chitin carbohydrates [e.g., Beta- $(1,3)$-glucan synthase]. This inhibition leads to osmotic imbalance and the microorganism unavailability (White et al., 1998).

Echinocandins are poorly absorbed in the gastrointestinal tract because of their high molecular weight and are used only intravenously. Their pharmacological properties are one of the causes for the FDA approval, also including their low toxicity (very rare side effects have been reported) and slowly metabolization. A daily injection is sufficient and in contrast to other antifungal agents, interactions between echinocandins and other drugs are rare (Denning, 2002). Combination therapy between Amphotericin B and echinocandins often leads to a synergistic or at least an additive effect.

\section{MECHANISM OF ANTIFUNGALS RESISTANCE}

The incidence of fungal infections has increased dramatically over the past three decades followed by the increase of the fungi resistance (Pfaller et al., 2011). These microorganisms develop resistance mechanisms against the fungistatic or fungicidal effects of the antifungal agents. The three main mechanisms are: (a) reduction of drug accumulation in the fungal cell, (b) decrease of the target affinity for the drug, and (c) change in the metabolism that prevents and/or affects drug's efficiency (Devi et al., 2011).

Currently the antifungal agents available are insufficient to fully treat the infections in patient populations. Therefore, the 
Table 1 | Comparison of the current features of the antifungal agents present in the market.

\begin{tabular}{|c|c|c|c|}
\hline Antifungic class & Molecule(s) & Target infection & References \\
\hline 5-Fluoropyrimidine & 5-Fluorocytosine & $\begin{array}{l}\text { Cryptococcosis, candidiasis, and chromoblastomycosis. } \\
\text { High minimum inhibitory concentration for some } \\
\text { strains of Aspergillus, Penicillium and several } \\
\text { Zygomycetes except for chromoblastomycosis, 5-FC is } \\
\text { always used in combination with amphotericin }\end{array}$ & Hope et al., 200 \\
\hline
\end{tabular}

Polyenes Amphotericin B, nystatin and natamycin

\author{
Amphotericin B: treatment of deep mycoses and \\ presents a broad spectrum of action, being useful in \\ the treatment of candidiasis, cryptococcosis, \\ histoplasmosis, blastomycosis, \\ paracoccidioidomycosis, cocciodioidomicosis, \\ aspergillosis, extracutaneous sporotrichosis, and some \\ cases of mucormycosis, hyalohyphomycosis and \\ phaeohyphomycosis. Nystatin is often applied for \\ treating cutaneous irritation and vaginal candidiasis \\ whereas natamycin can be utilized for the treatment of \\ keratinophilic fungi or corneal infections
}

\begin{tabular}{|c|c|c|c|}
\hline Azoles & $\begin{array}{l}\text { Two classes: imidazoles (ketoconazole, } \\
\text { miconazole, clotrimazole and econazole) } \\
\text { and triazoles (fluconazole, itraconazole, } \\
\text { voriconazole) }\end{array}$ & $\begin{array}{l}\text { Fluconazole: C. immitis, C. neoformans, and P. } \\
\text { brasiliensis, but lower activity against species as } \\
\text { Aspergillus, Fusarium, Scedosporium, Penicillium and } \\
\text { other filamentous fungi that cause invasive infections } \\
\text { Itraconazole: most Candida species, including } \\
\text { fluconazole- resistant strains, C. immitis, C. } \\
\text { neoformans, P. brasiliensis, H. capsulatum, } \\
\text { Blastomyces dermatitidis, Aspergillus fumigatus, A. } \\
\text { niger and Penicillium marneffei, and better than } \\
\text { fluconazole in the treatment of coccidioidomycosis, } \\
\text { paracoccidioidomycosis, not reaching the central } \\
\text { nervous system. } \\
\text { Voriconazole: a second-generation fluconazole } \\
\text { derivative whose activity against Candida species, } \\
\text { including C. krusei, more potent than fluconazole }\end{array}$ & $\begin{array}{l}\text { Fratti et al., 1998; Catalan } \\
\text { and Monteio, 2006; } \\
\text { Kamberi et al., } 2007\end{array}$ \\
\hline Echinocandins & $\begin{array}{l}\text { Caspofungin B pneumocandin } \\
\text { papulacandin }\end{array}$ & $\begin{array}{l}\text { The group composed of caspofungin, micafungin and } \\
\text { anidulofungin (4) (Figure 2) presents antifungal } \\
\text { spectrum restricted to species as Candida (e.g., } \\
\text { fungicides) and Aspergillus (e.g., fungistatics) }\end{array}$ & Denning, 2002, 2003 \\
\hline
\end{tabular}

Ascioglu et al., 2002;

Bovers et al., 2008;

Strushkevich et al., 2010

\author{
Fluconazole: C. immitis, C. neoformans, and $\mathrm{P}$. \\ Aspergillus, Fusarium, Scedosporium, Penicillium and \\ other filamentous fungi that cause invasive infections \\ Blastomyces dermatitidis, Aspergillus fumigatus, $A$. \\ derivative whose activity against Candida species,
} The group composed of caspofungin, micafungin and spectrum restricted to species as Candida (e.g. development of new antifungal agents has been continuously required in clinical therapy (Tang et al., 2010). At present, the major problem in the treatment of these infections and related diseases is the increasing appearance of multiresistant strains (MDR). This issue may be a consequence of errors in the drug disposal and the use of few and old medicines available in the market which failure in healing the disease. Factors as those related to the infection site, host immune response, strain virulence, drug pharmacokinetics and minimum inhibitory concentration (MIC) of the prescribed drug are also involved in fungi resistance emergence (Shapiro et al., 2011).

Mechanisms of resistance against antifungal may be associated with the entry of the molecule into the cell, its efflux, inactivation or degradation and activity on target cell (White et al., 1998). Azoles antifungals are commonly used, and consequently, there are reports about their antifungal mechanism, pharmacological properties, and resistance mechanisms (Vandeputte et al.,
2012). The prophylactic use of azoles (fluconazole) in neutropenic patients has an impact on the reduction of Candida related infections in this population (Lortholary and Dupont, 1997). On the other hand, the emergence of infections caused by fluconazole-resistant Candida, such as C. glabrata and C. krusei has been observed.

The prolonged use of prophylactic fluconazole in bone marrow transplant patients was associated with a higher occurrence of filamentous fungus infections (Marr et al., 2010). Besides, the use of new antifungal agents, for example, voriconazole (3) (Figure 2), was associated with increased numbers of zygomycosis in immunocompromised patients. The use of caspofungin in the treatment of $C$. krusei infection has also been associated with zygomycosis outbreak (Girmenia et al., 2005).

The global expansion of resistance to antifungal agents is an evolutionary response to the indiscriminate use of therapy for several decades. Despite the existing antifungal agents for the 


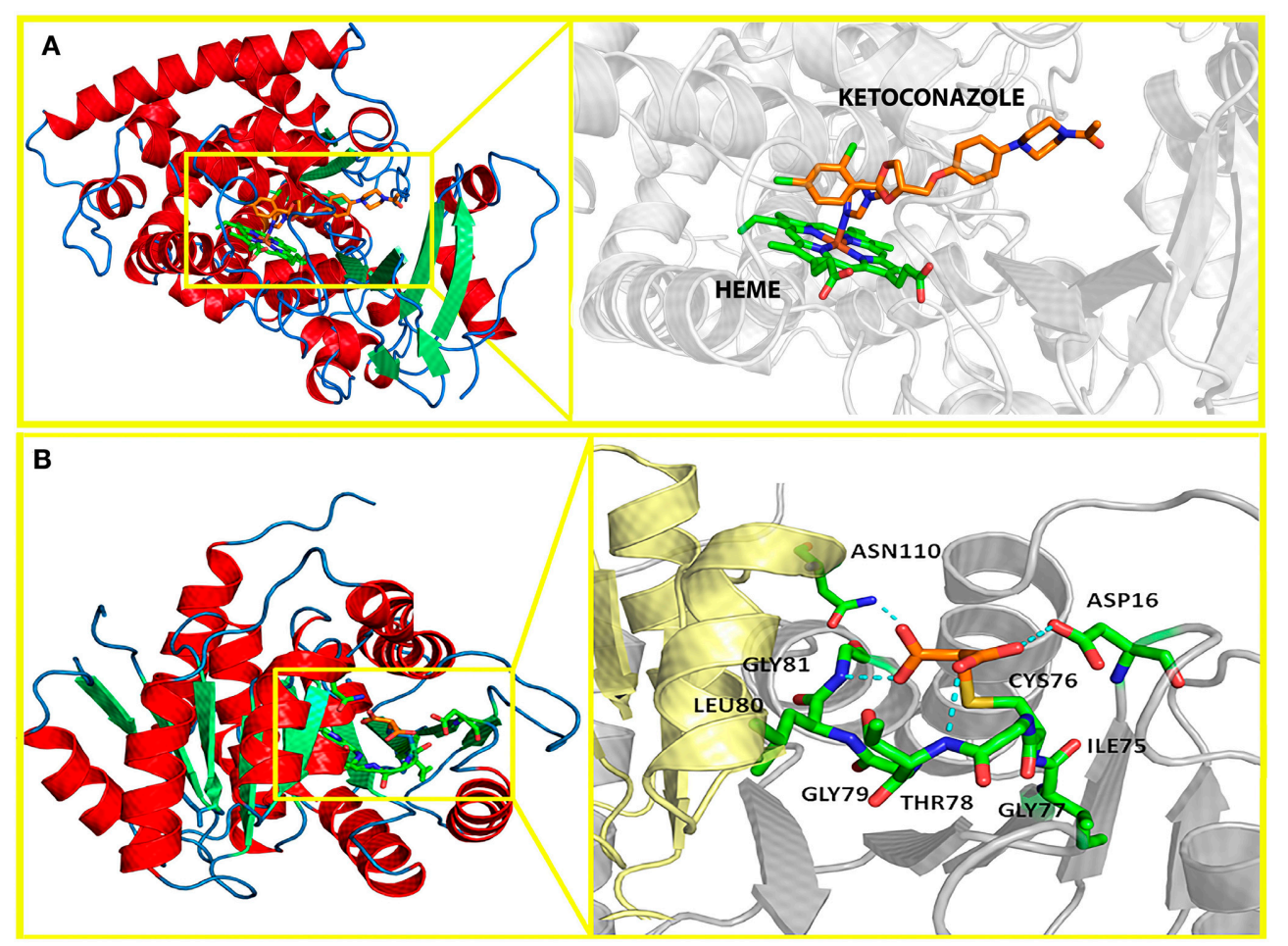

FIGURE 3 | Current and potential targets for marine products, respectively. (A) Lanosterol 14- $\alpha$-demethylase (CYP51), an essential enzyme in fungal sterol biosynthesis. The crystal of human CYP51 available in the Protein databank (PDB: 3LD6) allows to identify the inhibitor (ketoconazole) binding to the heme group.
(B) Ribose-5-phosphate isomerase B from the pathogenic fungus Coccidioides immitis plays an important role in the pentose phosphate pathway and nucleotide and co-factor biogenesis. The crystal structure shows the covalent bond between malonic acid and Cys76 of the enzyme. treatment, resistance has been the main and a greater challenge for scientists and pharmaceutical and biotechnology companies (Bremner et al., 2007; Kaufman, 2011). Altogether, these results revealed the importance of the specialist to perform the prescription of an antifungal agent and the urgent need for new options of treatment, including different approaches and molecules from different origins and mechanisms of action.

\section{BIOTECHNOLOGY AND SOME NEW OPTIONS FOR FUNGUS THERAPY AND PREVENTION \\ Different approaches and different alternative sources}

New antifungal agents that act on other targets than the drugs currently available as well as new immunological approaches to increase host response in the treatment and/or prevention of fungal infections are promising possibilities for future therapy of fungus infection (Groll et al., 2002; Ostrosky-Zeichner et al., 2010).

The need for discovering available drugs being able to control emerging infections and resistant strains stimulate the necessity to look for unconventional new sources of bioactive natural products. In this aspect, marine natural products could be an attractive field, (El Amraoui et al., 2014).

Natural products have been shown to be an excellent source of novel chemical entities. The discovery of caspofungin in treating invasive aspergillosis and candidiasis and of the 1,3- $\beta$-D-glucan synthase as a target for treatment of fungal infections has begun a new era for antifungal therapy (Onishi et al., 2000; Keating and Figgitt, 2003; Walker et al., 2011).

Literature described the isolation of antifungals from natural sources such as chryscandin, chaetiacandin, pyrrolnitrin and many other natural products are currently under investigation (Yamashita et al., 1984; Komori et al., 1985; Barrett, 2002). Peptides isolated from several animal species have also been studied, including those from the Brazilian snake venoms (Gomes et al., 2005) such as Crotamine, a peptide from Crotalus durissus terrificus venom active against Candida spp., Trichosporon spp., and Cryptococcus neoformans. The native crotamine so as the chemically produced synthetic crotamine showed similar activity, whereas recombinant crotamine was more potent in most assays (Yamane et al., 2013).

According to the literature, failure in therapy using the current antifungal compounds have been detected even when a specific pathogen is considered susceptible to them. This paradox highlights the need of an intact and efficient immune system to prevent invasive fungal infections and to effectively control infections (Casadevall and Pirofski, 2001; Pappas, 2004). The availability of granulocyte infusions, administration of cytokine growth factors, the use of recombinant cytokines, antibody therapy, and vaccines are some of the recent advances in biotechnology that have been studied for application in fungal therapy and prevention, 
especially in immunocompromised patients (Stevens et al., 2000; Casadevall and Pirofski, 2001).

Several studies have reported the search for new vaccines (Devi et al., 1991; Han et al., 1999; Segal, 1999; Stevens et al., 2000; Casadevall and Pirofski, 2001; Torosantucci et al., 2005; Spellberg et al., 2008; Liu and Filler, 2011; Sandini et al., 2011; Cassone and Casadevall, 2012), particularly against cryptococcosis, histoplasmosis (Georgopapadakou and Walsh, 1996; Chaturvedi and Wormley, 2013) coccidioidomycosis, blastomycosis and candidiasis (Segal, 1999; Barnato et al., 2001; Walsh, 2002; Cassone and Casadevall, 2012). Polysaccharide-protein conjugate vaccines were shown to be effective against Cryptococcus neoformans (Devi et al., 1991) and Candida albicans (Han et al., 1999). Recently, a polysaccharide-protein conjugate vaccine that uses the algal glucan, laminarin has shown to be immunogenic and to induce protection in mice against aspergillosis and candidiasis (Torosantucci et al., 2005).

\section{Marine natural product as antifungal agent}

Marine natural product bioprospecting has yielded a considerable number of drug candidates and can be used to produce several novel products that have applications in new medical technologies (Wijffels, 2008). During the last few years the scientific community has shown a considerable interest in the study of algal extract as sources of new compounds that might lead to therapeutically useful agents, especially novel antibiotics in order to combat new diseases and drug-resistant pathogens that are becoming a significant threat to public health (Guedes et al., 2012; Xiong et al., 2013). Marine derived have been proven to be a rich source of structurally unique and biologically active secondary metabolites with biological potential (Figure 2). A number of new metabolites have been isolated and identified and their biological activities have been evaluated (Molinski et al., 2009).

Extensive reviews on marine pharmacology have been described covering the varied biological activities found in these microorganisms as an anthelmintic, antibacterial, anticoagulant, antifungal, anti-inflammatory, antimalarial, protozoa, antituberculosis, antiviral activities (Bhatnagar and Kim, 2010; Mayer et al., 2013).

There is great interest in the research and investigation of the biological potential of both marine organisms and marine microorganisms as producers of new drugs including antifungics (Figures 2, 3) (Alghazeer et al., 2013).

Cyanobacteria and Algae. The antimicrobial activity of microalgae and macroalgae has been attributed to compounds belonging to several chemical classes, including insoles, terpenes, acetogenins, phenols, fatty acids and volatile halogenated hydrocarbons (Mhadhebi et al., 2012; Alghazeer et al., 2013) (Table 2).

Mhadhebi and coworkers evaluated 24 organic extracts obtained from six marine algae (the brown marine seaweeds, Cystoseira crinite, Cystoseira compressa, Cystoseira sedoides Dictyopteris membranaceae, and two red seaweeds Gelidium latifolium, and Halurus equisetifolius) collected from Tunisian Mediterranean coasts and discovered that algae $C$. crinita and C. sedoides showed an interesting result against C. albicans and C. kefyr with diameter of the inhibition zones between 23 and
$44.3 \mathrm{~mm}$ for the chloroformic extract and ethyl acetate extract (Mhadhebi et al., 2012).

Blue-green algae are rich sources of structurally novel and biologically active metabolites which are shown to exhibit anticancer, antimicrobial, antifungal or anti-inflammatory and other pharmacological activities. Kumar et al. (2013) observed that methanol extracts of the algae Phormidium fragile exhibited potential antifungal activity against Aspergillus flavus, Candida albicans, and Trichoderma viride (Kumar et al., 2013).

Interestingly, the phenolic content of extracts from two brown algae Padina pavonica and Sargassum vulgare from the Lebanese coast showed antioxidant and the antifungal activities (Khaled et al., 2012). In fact, the ethyl acetate fraction of the algae P. pavonica showed an interesting antifungal activity against Candida glabrata and C. krusei with diameter of inhibition with 16 and $14 \mathrm{~mm}$ respectively.

The red algae have been described as an important source of bioactive molecules. The Rhodophyta Asparagopsis taxiformis collected from the Straits of Messina (Italy) were screened for antifungal activity against Aspergillus species and showed great activity with MIC between 0.15 and $5 \mathrm{mg} \mathrm{m}^{-1}$ (Genovese et al., 2013). Specimens of the red alga Bostrychia tenella J. Agardh collected from São Paulo coast presented high activity in an antifungal assay with the phytopathogenic fungi Cladosporium cladosporioides and Cladosporium sphaerospermum (de Felício et al., 2010).

Dinoflagellates. Polyether macrolides compounds are very common among marine dinoflagellates. Goniodomin A (5) (Murakami et al., 1988) was isolated from various marine dinoflagellates, e.g., Goniodoma pseudogoniaulax and is an antifungal polyether macrolide (Murakami et al., 1988; Mizuno et al., 1998) as well as the gambieric acids (e.g., gambieric acid B) (7) (Figure 2) (Nagai et al., 1992).

Dinoflagellates are an important source of bioactives natural products, like amphidinols, lingshuiols and zooxanthellatoxins (Washida et al., 2006). Amphidinols (AMs) are an important class isolated from the dinoflagellates Amphidinium klebsii that presents potent antifungal acitivity with great membranedisrupting activity (Houdai et al., 2004), and in 2008 fourteen was estimated to have been isolated (Morsy et al., 2008). The AMs antifungal activity is probably due to the interaction with membrane lipids that increase the permeability (Houdai et al., 2005).

Washida and collaborators isolated two microbial polyol compounds from the cultured marine dinoflagellate Amphidinium sp.: Karatungiols A and B, and was observed for Karatungiol A antifungal activity against NBRC4407 Aspergillus niger (12 $\mu \mathrm{g} / \mathrm{disc})$ and antiprotozoan activity against Trichomonas foetus $(1 \mu \mathrm{g} / \mathrm{ml})$ (Washida et al., 2006) (Table 2).

Marine sponges. Marine sponges are among the richest sources of interesting chemicals produced by marine organisms (Laport et al., 2009). These organisms produce a wide variety of substances with antimicrobial activity, including terpenoids, alkaloids, nitrogenous metabolites, cyclic peptides, fatty acids, glycolipids, and macrolides (Gaspar et al., 2004; Sipkema et al., 2005). Among the antifungal activities from marine sponges 
Table 2 | Natural products from marine organisms with antifungal features.

\begin{tabular}{|c|c|c|c|c|}
\hline Algae source & Classification & Extracts & Target-microorganism & References \\
\hline Xylaria psidii, mycelium sterilium & Marine fungi & Ethyl acetate extracts & $\begin{array}{l}\text { C. maltose, Cladosporium } \\
\text { cucumerinum }\end{array}$ & Tarman et al., 2011 \\
\hline Nocardia sp. & Marine bacteria & Ayamycin, justicidin B & $\begin{array}{l}\text { C. neoformans, C. albicans, } \\
\text { A. niger }\end{array}$ & El-Gendy et al., 2008 \\
\hline Goniodoma pseudogoniaulax & Dinoflagellates & Goniodomin A & $\begin{array}{l}\text { Mortierella ramannianus, } \\
\text { C. albicans }\end{array}$ & Murakami et al., 1988 \\
\hline Amphidinium sp. & Dinoflagellates & Karatungiols & A. niger & Washida et al., 2006 \\
\hline Theonella swinhoei & Marine sponges & Bicyclic glycopeptide & $\begin{array}{l}\text { Amphotericin B-resistant strains } \\
\text { of C. albicans }\end{array}$ & Youssef et al., 2014 \\
\hline Theonella swinhoei & Marine sponges & Aurantosides & $\begin{array}{l}\text { C. albicans, C. parapsilosis, } \\
\text { C. glabrata, C. tropicalis, and } \\
\text { Fusarium solani }\end{array}$ & Angawi et al., 2011 \\
\hline Cystoseira crinita; Cystoseira sedoides & Macroalgae & Ethyl acetate & C. krusei, C. kefyr & Mhadhebi et al., 2012 \\
\hline Phormidium fragile & Blue-green algae & Methanol & $\begin{array}{l}\text { Aspergillus flavus, C. albicans, } \\
\text { Trichoderma viride }\end{array}$ & Kumar et al., 2013 \\
\hline Padina pavonica & Brown algae & Ethyl acetate fraction & C. glabrata, C. krusei & Khaled et al., 2012 \\
\hline Asparagopsis taxiformis & Red alga & Various extracts & A. flavus, A. fumigatus, A. Terreus & Genovese et al., 2013 \\
\hline Bostrychia tenella & Red algae & n-hexane dichloromethane & $\begin{array}{l}\text { Cladosporium Cladosporioides, } \\
\text { C. sphaerospermum }\end{array}$ & de Felício et al., 2010 \\
\hline Rhodomela confervoides & Red algae & Methanolic extracts & C. albicans & Saidani et al., 2012 \\
\hline
\end{tabular}

recently described, we highlight the activity $( \pm)$-Curcuphenol (6) and (+)-curcudiol (Figure 2) isolated from marine sponges against species such as Trichophyton mentagrophytes (Gaspar et al., 2004).

A new bicyclic glycopeptide, Theonellamide G, from the Red Sea Marine Sponge Theonella swinhoei showed potent antifungal activity toward wild and amphotericin B-resistant strains of Candida albicans with IC50 of 4.49 and $2.0 \mu \mathrm{M}$, respectively. Beyond that, it displayed cytotoxic activity against the human colon adenocarcinoma cell line (HCT-16) with IC50 of $6.0 \mu \mathrm{M}$ compared to $2.0 \mu \mathrm{M}$ for positive control (Youssef et al., 2014).

Another studies unveiled the potential of the marine products as Aurantosides, described in many studies with antifungal activity. Angawi and cols isolated four aurantosides, including a new compound Aurantoside J, from a Indonesian specimen of Theonella swinhoei and tested against C. albicans, C. parapsilosis, C. glabrata, C. tropicalis, and Fusarium solani (Angawi et al., 2011). The results reveal that Aurantoside I exhibited a very good antifungal effect against all the tested strains, especially for Candida. Interestingly the authors suggested that the mechanism of the antifungal action of aurantoside I could be related to the mechanism of other polyene antifungal agents as nystatin (Table 2).

The Aurantoside $\mathrm{K}$ was isolated from a marine sponge belonging to the genus Melophlus sp (Kumar et al., 2012) and evaluated their antifungal activity against different fungals with clinical importance and showed great antifungal activity against amphotericin-resistant $C$. albicans and wild type $C$. albicans with the MIC at 31.25 and $1.95 \mu \mathrm{g} / \mathrm{mL}$, respectively.

The Polyketides derived from marine sponges showed antifungal activity for Cryptococcus neoformans (Yu et al., 2012). In Brazilian coasts, the antifungal profile of 21 crude extracts obtained from marine sponges was evaluated against aflatoxin-producing strains of Aspergillus flavus. Finally,
Batzelladine L, isolated from the marine sponge Monanchora arbuscula and the extract of the sponge Amphimedon sp, which was shown to be enriched in halitoxins and amphitoxins showed potent antifungal activity that should be further explored (Arevabini et al., 2014).

Marine Microorganism. Most kinds of macroorganisms such as algae, sponges and corals have extensively been investigated for their natural products content. These macroorganisms also serve as hosts for microorganisms and were recently considered as an important source of natural products.

The marine environment is a habitat for many unique microorganisms, which produce biologically active compounds to adapt to particular environmental conditions (Penesyan et al., 2010). Marine bacteria and fungi are of considerable importance as new promising sources of a huge number of biologically active products. These marine microorganisms have proven to be an attractive source of new bioactive secondary metabolites (Yamazaki et al., 2012).

Marine microorganisms are known to produce bioactive substances in the marine environment, predominantly protecting themselves from environmental dangers such as predation and defense mechanisms for protecting their host organism. The microorganism generally accumulate structurally unique bioactive secondary metabolites not found in terrestrial (Debbab et al., 2010). In recent years, marine microbes have become important in the study of novel microbial products exhibiting antibacterial (Leyton et al., 2011), antiviral (Tong et al., 2012), antihelmintic (Dahiya and Gautam, 2011) properties. Microorganisms represent promising natural product sources having the advantage of large-scale cultivation and fermentation of the source organisms. Fungi produce a vast range of secondary metabolites and also believed to be prolific resources of natural products. 
Tarman et al. (2011) isolated 11 fungal strains from Indonesian marine habitats (Tarman et al., 2011). The ethyl acetate extracts of their culture broth were tested for cytotoxic activity against a urinary bladder carcinoma cell line and for antifungal and antibacterial activities. From the 11 isolates only four strains exhibited antifungal properties against Candida maltose. The fungal strain (KT29) displayed fungicidal properties against the plant pathogenic fungus Cladosporium cucumerinum.

The chemical constituents and antifungal activity of marine sponges Haliclona baeri and Haliclona cymaeformis from the Gulf of Thailand were investigated against Candida, Aspergillus and dermatophyte strains (Wattanadilok et al., 2007). The nortetillapyrone isolated showed some activity against $C$. Tropicalis $(2.0 \mu \mathrm{g} / \mathrm{ml})$ and good activity against C. Glabrata (62.5$31.25 \mu \mathrm{g} / \mathrm{ml})$, C. dubliniensis $(62.5 \mu \mathrm{g} / \mathrm{ml})$ and Cryptococcus neoformans $(31.25 \mu \mathrm{g} / \mathrm{ml})$. In Addition, this compound exhibited significant antifungal activity against dermatophytes with the MIC values ranging from 31.25 to $1.5 \mu \mathrm{g} / \mathrm{ml}$.

The diversity and antimicrobial activity of bacteria from the marine sponges Suberites carnosus and Leucosolenia sp were evaluated by Flemer and coworkers (Flemer et al., 2012). Two hundred and thirty-seven bacteria were isolated from these macroorganisms and 69 isolates showed clear activity against at least one of the test strains studied and reveal that both sponges possess a diverse range of bioactive and potentially novel bacteria. Interestingly, the results suggest that $S$. carnosus isolates may be a better source of antibacterial compounds, while Leucosolenia sp. Isolates seems to be a better source of antifungal compounds.

\section{CONCLUSIONS}

Altogether, these data showed herein point to the need of further studies to find new treatment options to fight against the fungus infections and the resistant strains. As part of our general interest in the isolation and characterization of bioactive metabolites from marine organisms with potential pharmaceutical, the marine natural products emerges as a potential source of antifungal substances that should be investigated clinically besides in vitro and in vivo. Biological targets for marine products include those already detected for other antifungals such as Lanosterol 14- $\alpha$-demethylase (CYP51) or new ones may be identified to overcome the current fungi resistance mechanisms, such as Ribose-5-phosphate isomerase B (Figure 3).

\section{ACKNOWLEDGMENT}

We thank FAPERJ, CAPES, CNPq, and PROPPi from Universidade Federal Fluminense for the financial support and fellowships.

\section{REFERENCES}

Adler-Moore, J. P., and Proffitt, R. T. (2008). Amphotericin B lipid preparations, what are the differences? Clin. Microbiol. Infect. 14, 25-36. doi: 10.1111/j.14690691.2008.01979.x

Alghazeer, R., Whida, F., Abduelrhman, E., Gammoudi, F., and Azwai, S. (2013). Screening of antibacterial activity in marine green, red and brown macroalgae from the western coast of Libya. Nat. Sci. 10, 7-14. doi: 10.4236/ns.2013.51002

Angawi, R. F., Bavestrello, G., Calcinai, B., Dien, H. A., Donnarumma, G., Tufano, M. A., et al. (2011). Aurantoside J, a new tetramic acid glycoside from Theonella swinhoei. Insights into the antifungal potential of aurantosides. Mar. Drugs 12, 2809-2817. doi: 10.3390/md9122809
Arevabini, C., Crivelenti, Y. D., Abreu, M. H., Bittencourt, T. A., Santos, M. F. C., Berlinck, R. G. S., et al. (2014). Antifungal activity of metabolites from the marine sponges Amphimedon sp. and Monanchora arbuscula against Aspergillus flavus strains isolated from peanuts (Arachis hypogaea). Nat. Prod. Commun. 1, 33-36.

Ascioglu, S., Rex, J. H., de Pauw, B., Bennett, J. E., Bille, J., Crokaert, F., et al. (2002). Invasive fungal infections cooperative group of the european organization for research and treatment of cancer; mycoses study group of the national institute of allergy and infectious diseases. Defining opportunistic invasive fungal infections in immunocompromised patients with cancer and hematopoietic stem cell transplants, an international consensus. Clin. Infect. Dis. 3, 7-14. doi: $10.1086 / 323335$

Barnato, A. E., Sanders, G. D., and Owens, D. K. (2001). Cost-effectiveness of a potential vaccine for Coccidioides immitis. Emerg. Infect. Dis. 7, 797-806. doi: 10.3201/eid0705.010505

Barrett, D. (2002). From natural products to clinically useful antifungals. Biochim. Biophys. Acta 1587, 224-233. doi: 10.1016/S0925-4439(02)00085-6

Bhatnagar, I., and Kim, S. K. (2010). Immense essence of excellence: marine microbial bioactive compounds. Mar. Drugs 10, 2673-2701. doi: 10.3390/md8102673

Bouza, E. and Munoz, P. (2008). Epidemiology of candidemia in intensive care units. Int. J. Antimicrob. Agents 32, S87-S91. doi: 10.1016/S09248579(08)70006-2

Bovers, M., Hagen, F., and Boekhout, T. (2008). Diversity of the Cryptococcus neoformans- Cryptococcus gattii species complex. Rev. Iberoam. Micol. 25, 4-12. doi: 10.1016/S1130-1406(08)70019-6

Bremner, J. B., Ambrus, J. I., and Samosom, S. (2007). Dual action-based approaches to antibacterial agents. Curr. Med. Chem. 14, 1459-1477. doi: $10.2174 / 092986707780831168$

Calderone, R. A., and Fonzi, W. A. (2001). Virulence factors of Candida albicans. Trends Microbiol. 9, 327-335. doi: 10.1016/S0966-842X(01)02094-7

Casadevall, A., and Pirofski, L. (2001). Adjunctive immune therapy for fungal infections. Clin. Infect. Dis. 33, 1048-1056. doi: 10.1086/322710

Cassone, A., and Casadevall, A. (2012). Recent progress in vaccines against fungal diseases. Curr. Opin. Microbiol. 15, 427-433. doi: 10.1016/j.mib.2012. 04.004

Catalan, M., and Monteio, J. C. (2006). Antifúngicos sistémicos. Farmacodinamia y farmacocinética. Rev. Iberoam. Micol. 23, 39-49. doi: 10.1016/S11301406(06)70012-2

Chaturvedi, A. K., and Wormley, F. L. (2013). Cryptococcus antigens and immune responses, implications for a vaccine. Expert Rev. Vaccines 11, 1261-1272. doi: 10.1586/14760584.2013.840094

Cheng, S. C., Joosten, L. A., Kullberg, B. J., and Netea, M. G. (2012). Interplay between Candida albicans and the mammalian innate host defense. Infect. Immun. 4, 1304-1131. doi: 10.1128/IAI.06146-11

Dahiya, R., and Gautam, H. (2011). Toward the synthesis and biological screening of a cyclotetrapeptide from marine bacteria. Mar. Drugs 1, 71-81. doi: $10.3390 / \mathrm{md} 9010071$

Debbab, A., Aly, A. H., Lin, W. H., and Proksch, P. (2010). Bioactive compounds from marine bacteria and fungi. Microb. Biotechnol. 5, 544-563. doi: 10.1111/j.1751-7915.2010.00179.x

de Felício, R., de Albuquerque, S., Young, M. C., Yokoya, N. S., and Debonsi, H. M. (2010). Trypanocidal, leishmanicidal and antifungal potential from marine red alga Bostrychia tenella J. Agardh (Rhodomelaceae, Ceramiales). J. Pharm. Biomed. Anal. 5, 763-769. doi: 10.1016/j.jpba.2010.02.018

Denning, D. W. (2002). Echinocandins, a new class of antifungal. J. Antimicrob. Chemother. 49, 889-891. doi: 10.1093/jac/dkf045

Denning, D. W. (2003). Echinocandin antifungal drugs. Lancet 362, 1142-1151. doi: 10.1016/S0140-6736(03)14472-8

Devi, P., Wahidulla, S., Kamat, T., and D'Souza, L. (2011). Screening marine organisms for antimicrobial activity against clinical pathogens. Indian J. Geomar. Sci. 40, 338-346.

Devi, S. J., Schneerson, R., Egan, W., Ulrich, T. J., Bryla, D., Robbins, J. B., et al. (1991). Cryptococcus neoformans serotype A glucuronoxylomannan-protein conjugate vaccines, synthesis, characterization, and immunogenicity. Infect. Immun. 10, 3700-3707.

Diaz, P. I., Xie, Z., Sobue, T., Thompson, A., Biyikoglu, B., Ricker, A., et al. (2012). Synergistic interaction between Candida albicans and commensal oral streptococci in a novel in vitro mucosal model. Infect. Immun. 2, 620-632. doi: 10.1128/IAI.05896-11 
Drgona, L., Khachatryan, A., Stephens, J., Charbonneau, C., Kantecki, M., Haider, S., et al. (2014). Clinical and economic burden of invasive fungal diseases in Europe, focus on pre-emptive and empirical treatment of Aspergillus and Candida species. Eur. J. Clin. Microbiol. Infect. Dis. 33,7-21. doi: 10.1007/s10096-013-1944-3

El Amraoui, B., E. Amraoui, M., and Cohen, N., Fassouane, A. (2014). Antifungal and antibacterial activity of marine microorganisms. Ann. Pharm. Fr. 72, 107-111. doi: 10.1016/j.pharma.2013.12.001

El-Gendy, M. M., Hawas, U. W., and Jaspars, M. (2008). Novel bioactive metabolites from a marine derived bacterium Nocardia Sp. ALAA 2000. J. Antibiot. (Tokyo) 6, 379-386. doi: 10.1038/ja.2008.53

Ellis, D. (2002). Amphotericin B, spectrum and resistance. J. Antimicrob. Chemother. 49, 7-10. doi: 10.1093/jac/49.suppl_1.7

Flemer, B., Kennedy, J., Margassery, L. M., Morrissey, J. P., O'Gara, F., and Dobson, A. D. (2012). Diversity and antimicrobial activities of microbes from two Irish marine sponges, Suberites carnosus and Leucosolenia sp. J. Appl. Microbiol. 2, 289-301. doi: 10.1111/j.1365-2672.2011.05211.x

Fratti, R. A., Belanger, P. H., and Sanati, H. (1998). The effect of the new triazole, voriconazole (UK-109,496), on the interactions of Candida albicans and Candida krusei with endothelial cells. J. Chemother. 10, 7-16. doi: 10.1179/joc.1998.10.1.7

Gaspar, H., Feio, S. S., Rodrigues, A. I., and Soest, R. V. (2004). Antifungal Activity of (+)-Curcuphenol, a Metabolite from the Marine Sponge Didiscus oxeata. Mar. Drugs 2, 8-13. doi: 10.3390/md201008

Gauthier, G. M., and Keller, N. P. (2013). Crossover fungal pathogens, the biology and pathogenesis of fungi capable of crossing kingdoms to infect plants and humans. Fungal Genet. Biol. 8, 1-12. doi: 10.1016/j.fgb.2013. 08.016

Genovese, G., Leitner, S., Minicante, S. A., and Lass-Flörl, C. (2013). The Mediterranean red alga Asparagopsis taxiformis has antifungal activity against Aspergillus species. Mycoses 5, 516-519. doi: 10.1111/myc.12065

Georgopapadakou, N., and Walsh, T. H. (1996). Antifungal therapy chemotherapeutic targets and immunologic strategies. Antimicrob. Agents Chemother. 40, 279-291.

Girmenia, C., Moleti, M. L., Micozzi, A., Lori, A. P., Barberi, W., Foa, R., and Martino, P. (2005). Breakthrough Candida krusei fungemia during fluconazole prophylaxis followed by breakthrough zygomycosis during caspofungin therapy in a patient with severe aplastic anemia who underwent stem cell transplantation. J. Clin. Microbiol. 43, 5395-5396. doi: 10.1128/JCM.43.10.5395-5396.2005

Gomes, V. M., Carvalho, A. O., Da Cunha, M., Keller, M. N., Bloch, C. Jr., Deolindo, P., et al. (2005). Purification and characterization of a novel peptide with antifungal activity from Bothropsjararaca venom. Toxicon 45, 817-827. doi: 10.1016/j.toxicon.2004.12.011

Groll, A. H., Thomas, M. D., and Walsh, M. D. (2002). Invasive fungal infections in the neutropenic cancer patient, current approaches and future strategies. Infect. Med. 19, 326-334.

Guedes, E. A., Araújo, M. A., Souza, A. K., de Souza, L. I., de Barros, L. D., Maranhão, F. C., et al. (2012). Antifungal activities of different extracts of marine macroalgae against dermatophytes and Candida species. Mycopathologia 3, 223-232. doi: 10.1007/s11046-012-9541-Z

Han, Y., Ulrich, M., and Cutler, J. E. (1999). Candida albicans mannan extractprotein conjugates induce a protective immune response against experimental candidiasis. J. Infect. Dis. 179, 1477-1484. doi: 10.1086/314779

Harris, R. (2002). Progress with superficial mycosis using essential oils. Int. J. Aromather. 12, 83-91. doi: 10.1016/S0962-4562(02)00032-2

Hellio, C., Pons, A. M., Beaupoil, C., Bourgougnon, N., and Le, G.al, Y. (2012). Antibacterial, antifungal and cytotoxic activities of extracts from fish epidermis and epidermal mucus. Int. J. Antimicrob. Agents 20, 214-219. doi: 10.1016/S0924-8579(02)00172-3

Hope, W. W., Tabernero, L., Denning, D. W., and Anderson, M. J. (2004). Molecular mechanisms of primary resistance to flucytosine in Candida albicans. Antimicrob. Agents Chemother. 48, 4377-4386. doi: 10.1128/AAC.48.11.43774386.2004

Houdai, T., Matsuoka, S., Matsumori, N., and Murata, M. (2004). Membranepermeabilizing activities of amphidinol 3, polyene-polyhydroxy antifungal from a marine dinoflagellate. Biochim. Biophys. Acta 1, 91-100 doi: 10.1016/j.bbamem.2004.09.002

Houdai, T., Matsuoka, S., Morsy, N., Matsumori, N., Satake, M., and Murata, M. (2005). Hairpin conformation of amphidinols possibly accounting for potent membrane permeabilizing activities. Tetrahedron 61, 2795-2802. doi: 10.1016/j.tet.2005.01.069

Jain, B. B., Bose, D., Mondal, R., and Chattopadhyay, S. (2014). Disseminated cryptococcosis in an immunocompetent child. Turk Patoloji Derg. 27. doi: 10.5146/tjpath.2014.01230. [Epub ahead of print].

Jordán, I., Hernandez, L., Balaguer, M., López-Castilla, J. D., Casanueva, L., Shuffelman, C., et al. (2014). C. albicans, C. parapsilosis and C. tropicalis invasive infections in the PICU: clinical features, prognosis and mortality. Rev. Esp. Quimioter. 27, 56-62.

Juyal, D., Sharma, M., Pal, S., Rathaur, V. K., and Sharma, N. (2013). Emergence of non-albicans Candida species in neonatal candidemia. N. Am. J. Med. Sci. 5, 41-45. doi: 10.4103/1947-2714.118919

Kamberi, P., Sobel, R. A., Clemons, K. V., Waldvogel, A., Striebel, J. M., Williams, P. L., et al. (2007). Comparison of itraconazole and fluconazole treatments in a murine model of coccidioidal meningitis. Antimicrob. Agents Chemother. 51, 998-1003. doi: 10.1128/AAC.00332-06

Kaufman, G. (2011). Antibiotics, mode of action and mechanisms of resistance. Nurs Stand. 25, 49-55. doi: 10.7748/ns2011.06.25.42.49.c8583

Keating, G., and Figgitt, D. (2003). Caspofungin, a review of its use in oesophageal candidiasis, invasive candidiasis and invasive aspergillosis. Drugs 63, 2235-2263. doi: 10.2165/00003495-200363200-00008

Khaled, N., Hiba, M., and Asma, C. (2012). Antioxidant and antifungal activities of Padina pavonica and Sargassum vulgare from the Lebanese Mediterranean Coast. Adv. Environ. Biol. 1, 42-48.

Kim, H. A., Hyun, M., and Ryu, S. Y. (2013). Catheter-Associated Rhodotorula mucilaginosa Fungemia in an Immunocompetent Host. Infect. Chemother. 3, 339-342. doi: 10.3947/ic.2013.45.3.339

Komori, T., Yamashita, M., Tsurumi, Y., and Kohsaka, M. (1985). Chaetiacandin, a novel papulacandin, I. Fermentation, isolation and characterization. J. Antibiot. 38, 455-459. doi: 10.7164/antibiotics.38.455

Kousha, M., Tadi, R., and Soubani, A. O. (2011). Pulmonary aspergillosis, a clinical review. Eur. Respir. Ver. 20, 156-174. doi: 10.1183/09059180.00001011

Kumar, N. S. S., Sivasubramanian, V., and Mukund, S. (2013). Antimicrobial and Antifungal activity of extracts of Phormidium fragile Gomont. J. Algal Biomass Utln. 3, 66-71.

Kumar, R., Chaturvedi, A. K., Shukla, P. K., and Lakshmi, V. (2007). Antifungal activity in triterpene glycosides from the sea cucumber Actinopyga lecanora. Bioorg. Med. Chem. Lett. 15, 4387-4391. doi: 10.1016/j.bmcl.2006.12.052

Kumar, R. S., Subramani, R., Feussner, K. D., and Aalbersberg, W. (2012). Aurantoside K, a new antifungal tetramic acid glycoside from a Fijian Marine sponge of the genus Melophlus Rohitesh. Mar. Drugs 10, 200-208. doi: 10.3390/md10010200

Laport, M. S., Santos, O. C., and Muricy, G. (2009). Marine sponges, potential sources of new antimicrobial drugs. Curr. Pharm. Biotechnol. 1,86-105. doi: $10.2174 / 138920109787048625$

Leyton, Y., Borquez, J., Darias, J., Cueto, M., Díaz-Marrero, A. R., and Riquelme, C. (2011). Oleic acid produced by a marine Vibrio spp. acts as anti-Vibrio parahaemolyticus agent. Mar. Drugs 10, 2155-2163. doi: 10.3390/md9102155

Liu, Y., and Filler, S. G. (2011). Candida albicans Als3, a multifunctional adhesin and invasin. Eukaryot. Cell 12, 168-173. doi: 10.1128/EC.00279-10

Lortholary, O., and Dupont, B. (1997). Azole antifungal agents in the prevention of fungal infections in neutropenic patients and bone marrow graft recipients. Ann. Med. Interne. 148, 258-267.

Mabey, J. E., Anderson, M. J., Giles, P. F., Miller, C. J., Attwood, T. K., Paton, N. W., et al. (2004). CADRE: the Central Aspergillus Data REpository. Nucleic Acids Res. 1, D401-D405. doi: 10.1093/nar/gkh009

Marques, S. A. (2012). Paracoccidioidomycosis. Clin Dermatol. 30, 610-615. doi: 10.1016/j.clindermatol.2012.01.006

Marr, K. A., Carter, R., Myersond, D., Boeckh, M., and Corey, L. (2010). Aspergillosis in HSCT recipients, evidence for two distinct pathophysiologic conditions associated with engraftment status. Blood 96, 787.

Mayer, A. M. S., and Hamann, M. T. (2002). Marine pharmacology in 1999 , compounds with antibacterial, anticoagulant, antifungal, anti-inflammatory, anthelmintic, anti-inflammatory, antiplatelet, antiprotozoal and antiviral activities; affecting the cardiovascular, endocrine, immune, and nervous systems; and other miscellaneous mechanisms of action. Comp. Biochem. Physiol. C Toxicol. Pharmacol. 132, 315-339. doi: 10.1016/S1532-0456(02)00094-7

Mayer, A. M. S., and Hamann, M. T. (2004). Marine pharmacology in 2000, Marine compounds with antibacterial, anticoagulant, antifungal, anti-inflammatory, 
antimalarial, antiplatelet, antituberculosis, and antiviral activities; affecting the cardiovascular, immune, and nervous systems and other miscellaneous mechanisms of action. Mar. Biotechnol. 6, 37-52. doi: 10.1007/s10126-003-0007-7

Mayer, A. M. S., and Hamannm, M. T. (2005). Marine pharmacology in 2001-2002, Marine compounds with anthelmintic, antibacterial, anticoagulant, antidiabetic, antifungal, anti-inflammatory, antimalarial, antiplatelet, antiprotozoal, antituberculosis, and antiviral activities; Affecting the cardiovascular, immune and nervous systems and other miscellaneous mechanisms of action. Comp. Biochem. Physiol. 140, 265-286. doi: 10.1016/j.cca.2005.04.004

Mayer, A. M. S., and Lehmann, V. K. B. (2000). Marine pharmacology in 1998, Marine compounds with antibacterial, anticoagulant, antifungal, antiinflammatory, anthelmintic, antiplatelet, antiprotozoal, and antiviral activities; with actions on the cardiovascular, endocrine, immune, and nervous systems; and other miscellaneous mechanisms of action. Pharmacologist 42, 62-69.

Mayer, A. M. S., Rodríguez, A. D., Berlinck, R. G., and Fusetani, N. (2011). Marine pharmacology in 2007-8, Marine compounds with antibacterial, anticoagulant, antifungal, anti-inflammatory, antimalarial, antiprotozoal, antituberculosis, and antiviral activities; Affecting the immune and nervous system, and other miscellaneous mechanisms of action. Comp. Biochem. Physiol. C Toxicol. Pharmacol 153, 191-222. doi: 10.1016/j.cbpc.2010.08.008

Mayer, A. M. S., Rodríguez, A. D., Berlinck, R. G., and Hamann, M. T. (2007). Marine pharmacology in 2003-4, Marine compounds with anthelmintic, antibacterial, anticoagulant, antifungal, anti-inflammatory, antimalarial, antiplatelet, antiprotozoal, antituberculosis, and antiviral activities; Affecting the cardiovascular, immune and nervous systems, and other miscellaneous mechanisms of action. Comp. Biochem. Physiol. C Toxicol. Pharmacol. 145, 553-581. doi: 10.1016/j.cbpc.2007.01.015

Mayer, A. M. S., Rodríguez, A. D., Berlinck, R. G., and Hamann, M. T. (2009). Marine pharmacology in 2005-6, Marine compounds with anthelmintic, antibacterial, anticoagulant, antifungal, anti-inflammatory, antimalarial, antiprotozoal, antituberculosis, and antiviral activities; Affecting the cardiovascular, immune and nervous systems, and other miscellaneous mechanisms of action. Biochim. Biophys. Acta 1790, 283-308. doi: 10.1016/j.bbagen.2009.03.011

Mayer, A. M. S., Rodríguez, A. D., Taglialatela-Scafati, O., and Fusetani, N. (2013). Marine Pharmacology in 2009-2011, Marine compounds with antibacterial, antidiabetic, antifungal, anti-inflammatory, antiprotozoal, antituberculosis, and antiviral activities; Affecting the immune and nervous systems, and other miscellaneous mechanisms of action. Mar. Drugs 11, 2510-2573. doi: 10.3390/md11072510

Mhadhebi, L., Chaiebb, K., and Bouraouia, A. (2012). Evaluation of antimicrobial activity of organic fractions of six marine algae from Tunisian Mediterranean coasts. Int. J. Pharm. Pharm. Sci. 1, 534-537.

Mizuno, K., Nakahata, N., Ito, E., Murakami, M., Yamaguchi, K., and Ohizumi, Y. (1998). Goniodomin, A. An antifungal polyether macrolide, increases the filamentous actin content of $1321 \mathrm{~N} 1$ human astrocytoma cells. J. Pharm. Pharmacol. 6, 645-648. doi: 10.1111/j.2042-7158.1998.tb06899.x

Molinski, T. F., Dalisay, D. S., Lievens, S. L., and Saludes, J. P. (2009). Drug development from marine natural products. Nat. Rev. Drug Disc. 8, 69-85. doi: $10.1038 / \mathrm{nrd} 2487$

Morsy, N., Konoki, K., Houdai, T., Matsumori, N., Oishi, T., Murata, M., et al. (2008). Roles of integral protein in membrane permeabilization by amphidinols. Biochim. Biophys. Acta 6, 1453-1459. doi: 10.1016/j.bbamem.2008.01.018

Muhammed, M., Anagnostou, T., Desalermos, A., Kourkoumpetis, T. K., Carneiro, H. A., Glavis-Bloom, J., et al. (2013). Fusarium infection: report of 26 cases and review of 97 cases from the literature. Medicine (Baltimore). 6, 305-316. doi: 10.1097/MD.0000000000000008

Muhammed, M., Coleman, J. J., Carneiro, H. A., and Mylonakis, E. (2011). The challenge of managing fusariosis. Virulence 2, 91-96. doi: 10.4161/viru.2.2.15015

Murakami, M., Makabe, K., Yamaguchi, K., and Konosu, S. (1988). Goniodomin A, a novel polyether macrolide from the dinoflagellate goniodoma pseudogoniaulax. Tetrahedron Lett. 10, 1149-1152. doi: 10.1016/S0040-4039(00)86674-5

Nagai, H., Murata, M., Torigoe, K., Satake, M., and Yasumoto, T. (1992). Gambieric acids, new potent antifungal substances with unprecedented polyether structures from a marine dinoflagellate Gambierdiscus toxicus. J. Org. Chem. 57, 5448-5453. doi: 10.1021/jo00046a029

Nucci, M., Varon, A. G., Garnica, M., Akiti, T., Barreiros, G., Trope, B. M., et al. (2013). Increased incidence of invasive fusariosis with cutaneous portal of entry, Brazil. Emerg. Infect. Dis. 19, 1567-1572. doi: 10.3201/eid1910. 120847

Onishi, J., Meinz, M., Thompson, J., Curotto, J., Dreikorn, S., Rosenbach, M., et al. (2000). Discovery of novel antifungal $(1,3)$-beta-D-glucan synthase inhibitors. Antimicrob. Agents Chemother. 44, 368-377. doi: 10.1128/AAC.44.2.368377.2000

Ostrosky-Zeichner, L., Casadevall, A., Galgiani, J. N., Odds, F. C., and Rex, J. H. (2010). An insight into the antifungal pipeline: selected new molecules and beyond. Nat. Rev. Drug Discov. 9, 719-727. doi: 10.1038/nrd3074

Pappas, P. G. (2004). Immunotherapy for invasive fungal infections, from bench to bedside. Drug Resist. Updat. 7, 3-10. doi: 10.1016/j.drup.2003.12.002

Penesyan, A.1., Kjelleberg, S., and Egan, S. (2010). Development of novel drugs from marine surface associated microorganisms. Mar. Drugs 3, 438-459. doi: $10.3390 / \mathrm{md} 8030438$

Petatán-Sagahón, I., Anducho-Reyes, M. A., Silva-Rojas, H. V., Arana-Cuenca, A., Tellez-Jurado, A., Cárdenas-Álvarez, I. O., et al. (2011). Isolation of bacteria with antifungal activity against the phytopathogenic Fungi Stenocarpella maydis and Stenocarpella macrospora. Int. J. Mol. Sci. 12, 5522-5537. doi: 10.3390/ijms 12095522

Pfaller, M. A., Moet, G. J., Messer, S. A., Jones, R. N., and Castanheira, M. (2011). Geographic variations in species distribution and echinocandin and azole antifungal resistance rates among Candida bloodstream infection isolates, Report from the SENTRY Antimicrobial Surveillance Program (2008 to 2009). J. Clin. Microbiol. 49, 396-399. doi: 10.1128/JCM.01398-10

Piao, S. J., Song, Y. L., Jiao, W. H., Yang, F., Liu, X. F., Chen, W. S., et al. (2013). Hippolachnin A, a new antifungal Polyketide from the South China Sea Sponge Hippospongia lachne. Org. Lett. 15, 3526-3529. doi: 10.1021/ol400933x

Quian, J., Gutiérrez, S., González, V., Sánchez, M., Abayian, M., and Baccino, F. (2012). Meningitis por Cryptococcus neoformans em niños y adolescentes infectados por virus de la inmunodeficiencia humana. Rev. chil. Infectol. 29, 554-557. doi: 10.4067/S0716-10182012000600016

Richardson, M. D. (2005). Changing patterns and trends in systemic fungal infections. J. Antimicrob. Chemother. 56, i5-i11. doi: 10.1093/jac/dki218

Saidani, K., Bedjou, F., Benabdesselam, F., and Touati, N. (2012). Antifungal activity of methanolic extracts of four Algerian marine algae species. Afr. J. Biotechnol. 39, 9496-9500. doi: 10.5897/AJB11.1537

Sandini, S., La Valle, R., Deaglio, S., Malavasi, F., Cassone, A., and De Bernardis, F. (2011). A highly immunogenic recombinant and truncated protein of the secreted aspartic proteases family (rSap2t) of Candida albicans as a mucosal anticandidal vaccine. FEMS Immunol. Med. Microbiol. 62, 215-224. doi: 10.1111/j.1574-695X.2011.00802.x

Sathiamoorthy, B., Gupta, P., Kumar, M., Chaturvedi, A., Shuklhukla, P. K., and Rakesh, M. (2006). New antifungal flavonoid glycoside from Vitex negundo. Bioorg. Med. Chem. Lett. 1, 239-242. doi: 10.1016/j.bmcl.2006.09.051

Schieffelin, J. S., Garcia-Diaz, J. B., Loss, G. E. Jr., Beckman, E. N., Keller, R. A., Staffeld-Coit, C., et al. (2014). Phaeohyphomycosis fungal infections in solid organ transplant recipients: clinical presentation, pathology, and treatment. Transpl. Infect. Dis. 2, 270-278. doi: 10.1111/tid.12197

Scott, L. J., and Simpson, D. (2007). Voriconazole, a review of its use in the management of invasive fungal infections. Drugs 2, 269-298. doi: 10.2165/00003495200767020-00009

Segal, E. (1999). Experimental candidosis. Pathogenesis, prevention, therapy. Mycoses 42, 55-59.

Shapiro, R. S., Robbins, N., and Cowen, L. E. (2011). Regulatory circuitry governing fungal development, drug resistance, and disease. Microbiol. Mol. Biol. Rev. 2, 213-267. doi: 10.1128/MMBR.00045-10

Silva, S., Negri, M., Henriques, M., Oliveira, R., Williams, D. W., and Azeredo, J. (2012). Candida glabrata, Candida parapsilosis and Candida tropicalis: biology, epidemiology, pathogenicity and antifungal resistance. FEMS Microbiol. Rev. 36, 288-305. doi: 10.1111/j.1574-6976.2011.00278.x

Sipkema, D., Franssen, M. C., Osinga, R., Tramper, J., and Wijffels, R. H. (2005). Marine sponges as pharmacy. Mar. Biotechnol. 3,142-162. doi: 10.1007/s10126004-0405-5

Spellberg, B., Ibrahim, A. S., Lin, L., Avanesian, V., Fu, Y., Lipke, P., et al. (2008). Antibody titer threshold predicts anticandidal vaccine efficacy even though the mechanism of protection is induction of cell-mediated immunity. J. Infect. Dis. 7, 957-971. doi: 10.1086/529204

Stevens, D. A., Kullberg, B. J., Brummer, E., Casadevall, A., Netea, M. G., and Sugar, A. M. (2000). Combined treatment, antifungal drugs with antibodies, 
cytokines or drugs. Med. Mycol. 38, 305-315. doi: 10.1080/mmy.38.s1. 305.315

Strushkevich, N., Usanov, S. A., and Park, H. W. (2010). Structural basis of human CYP51 inhibition by antifungal azoles. J. Mol. Biol. 9, 1067-1078. doi: 10.1016/j.jmb.2010.01.075

Sun, W., Su, J., Xu, S., and Yan, D. (2012). Trichosporon asahii causing nosocomial urinary tract infections in intensive care unit patients: genotypes, virulence factors and antifungal susceptibility testing. J. Med. Microbiol. 12, 1750-1757. doi: 10.1099/jmm.0.049817-0

Tang, H., Zheng, C., Lv, J., Wu, J., Li, Y., Yang, H., et al. (2010). Synthesis and antifungal activities in vitro of novel pyrazino [2,1-a] isoquinolin derivatives. Bioorg. Med. Chem. Lett. 3, 979-982. doi: 10.1016/j.bmcl.2009.12.050

Tarman, K., Lindequist, U., Wende, K., Porzel, A., Arnold, N., and Wessjohann, L. A. (2011). Isolation of a new natural product and cytotoxic and antimicrobial activities of extracts from fungi of Indonesian marine habitats. Mar. Drugs 3, 294-306. doi: 10.3390/md9030294

Teixeira, C. A., Medeiros, P. B., Leushner, P., and Almeida, F. (2013). Rhinocerebral mucormycosis: literature review apropos of a rare entity. BMJ Case Rep. 2013:bcr2012008552. doi: 10.1136/bcr-2013-008552

Tkackz, J. S., and Didomenico, B. (2001). Antifungals, what's in pipeline. Cur. Opin. Microbiol. 4, 510-515. doi: 10.1016/S1369-5274(00)00248-4

Tong, J., Trapido-Rosenthal, H., Wang, J., Wang, Y., Li, Q. X., and Lu, Y. (2012). Antiviral activities and putative identification of compounds in microbial extracts from the Hawaiian coastal waters. Mar. Drugs 3, 521-538. doi: $10.3390 / \mathrm{md} 10030521$

Torosantucci, A., Bromuro, C., Chiani, P., De Bernardis, F., Berti, F., Galli, C., et al. (2005). A novel glyco-conjugate vaccine against fungal pathogens. J. Exp. Med. 5, 597-606. doi: 10.1084/jem.20050749

Tortorano, A. M., Richardson, M., Roilides, E., van Diepeningen, A., Caira, M., Munoz, P., et al. (2014). ESCMID and ECMM joint guidelines on diagnosis and management of hyalohyphomycosis: Fusarium spp., Scedosporium spp. and others. Clin. Microbiol. Infect. 20, 27-46. doi: 10.1111/1469-0691.12465

Umayaparvathi, S., Arumugam, M., Meenakshi, S., and Balasubramanian, T. (2012). Studies on antifungal, cytotoxic activities of mollusks and echinoderm extracts from southeast coast of India. Asian J. Pharm. Biol. Res. 2, 198-203.

Vandeputte, P., Selene, F., and Coste, A. T. (2012). Antifungal resistance and new strategies to control fungal infections. Int. J. Microbiol. 2012:713687. doi: $10.1155 / 2012 / 713687$

Vermes, A., Guchelaar, H. J., and Dankert, J. (2000). Flucytosine, a review of its pharmacology, clinical indications, pharmacokinetics, toxicity and drug interactions. J. Antimicrob. Chemother. 2, 171-179. doi: 10.1093/jac/46.2.171

Walker, S. S., Xu, Y., Triantafyllou, I., Waldman, M. F., Mendrick, C., Brown, N., et al. (2011). Discovery of a novel class of orally active antifungal beta-1,3-Dglucan synthase inhibitors. Antimicrob. Agents Chemother. 11, 5099-5106. doi: 10.1128/AAC.00432-11

Walsh, T. J. (2002). Echinocandins - an advance in the primary treatment of invasive candidiasis. N. Engl. J. Med. 25, 2070-2072. doi: 10.1056/NEJMe020142

Waness, A., Dawsari, G. A., and Al Jahdali, H. (2009). The rise of an opportunistic infection called "Invasive Zygomycosis." J. Glob. Infect. Dis. 1, 131-138. doi: 10.4103/0974-777X.56256

Washida, K., Koyama, T., Yamada, K., Kita, M., and Uemura, D. (2006). Karatungiols A and B, two novel antimicrobial polyol compounds, from the symbiotic marine dinoflagellate Amphidinium sp. Tetrahedron Lett. 47, 2521-2525. doi: 10.1016/j.tetlet.2006.02.045

Wattanadilok, R., Sawangwong, P., Rodrigues, C., Cidade, H., Pinto, M., Pinto, E., et al. (2007). Antifungal activity evaluation of the constituents of Haliclona baeri and Haliclona cymaeformis, collected from the Gulf of Thailan. Mar. Drugs 5, 40-51. doi: 10.3390/md502040

White, T. C., Marr, K. A., and Bowden, R. A. (1998). Clinical, cellular, and molecular factors that contribute to antifungal drug resistance. Clin. Microbiol. 11, 382-402.

Wijffels, R. H. (2008). Potential of sponges and microalgae for marine biotechnology. Trends Biotechnol. 1, 26-31. doi: 10.1016/j.tibtech.2007.10.002

Wisplinghoff, H. (2004). Nosocomial bloodstream infections in US hospitals, analysis of 24,179 cases from a prospective nationwide surveillance study. Clin. Infect. Dis. 39, 309-317. doi: 10.1086/421946

Xiong, Z. Q., Wang, J. F., Hao, Y. Y., and Wang, Y. (2013). Recent advances in the discovery and development of marine microbial natural products. Mar. Drugs 3, 700-717. doi: 10.3390/md11030700

Yamane, E. S., Bizerra, F. C., Oliveira, E. B., Moreira, J. T., Rajabi, M., Nunes, G. L., et al. (2013). Unraveling the antifungal activity of a South American rattlesnake toxin crotamine. Biochimie 2, 231-240. doi: 10.1016/j.biochi.2012.09.019

Yamashita, M., Tsurumi, Y., Hosoda, J., Komori, T., Kohsaka, M., and Imanaka, H. (1984). Chryscandin, a novel peptidyl nucleoside antibiotic, I. Taxonomy, fermentation, isolation and characterization. J. Antibiot. 11, 1279-1283. doi: 10.7164/antibiotics.37.1279

Yamazaki, H., Rotinsulu, H., Kaneko, T., Murakami, K., Fujiwara, H., Ukai, K., et al. (2012). A new dibenz[b,e]oxepine derivative, 1-hydroxy-10-methoxydibenz[b,e]oxepin-6,11-dione, from a marine-derived fungus, Beauveria bassiana TPU942. Mar. Drugs 12, 2691-2697. doi: 10.3390/md10122691

Youssef, D. T., Shaala, L. A., Mohamed, G. A., Badr, J. M., Bamanie, F. H., and Ibrahim, S. R. (2014). Theonellamide G, a potent antifungal and cytotoxic bicyclic glycopeptide from the Red Sea marine sponge Theonella swinhoei. Mar. Drugs 4, 1911-1923. doi: 10.3390/md12041911

Yu, H. B., Liu, X. F., Xu, Y., Gan, J. H., Jiao, W. H., Shen, Y., et al. (2012) Woodylides A-C, new cytotoxic linear polyketides from the South China Sea sponge Plakortis simplex. Mar. Drugs 10, 1027-1036. doi: 10.3390/md10051027 Zmeili, O. S. and Soubani, A. O. (2007). Pulmonary aspergillosis: a clinical update. QJM 100, 317-334. doi: 10.1093/qjmed/hcm035

Zonios, D. I. and Bennet, J. E. (2008). Update on azole antifungals. Semin. Respir. Crit. Care Med. 29, 198-210. doi: 10.1055/s-2008-1063858

Zotchev, S. B. (2003). Polyene macrolide antibiotics and their applications in human therapy. Curr. Med. Chem. 3, 211-223. doi: 10.2174/0929867033368448

Conflict of Interest Statement: The authors declare that the research was conducted in the absence of any commercial or financial relationships that could be construed as a potential conflict of interest.

Received: 18 February 2014; accepted: 15 May 2014; published online: 03 June 2014. Citation: Terra L, Abreu PA, Teixeira VL, Paixão ICP, Pereira R, Leal B, Lourenço AL, Rampelotto PH and Castro HC (2014) Mycoses and Antifungals: reviewing the basis of a current problem that still is a biotechnological target for marine products. Front. Mar. Sci. 1:12. doi: 10.3389/fmars.2014.00012

This article was submitted to Marine Biotechnology, a section of the journal Frontiers in Marine Science.

Copyright (C) 2014 Terra, Abreu, Teixeira, Paixão, Pereira, Leal, Lourenço, Rampelotto and Castro. This is an open-access article distributed under the terms of the Creative Commons Attribution License (CC BY). The use, distribution or reproduction in other forums is permitted, provided the original author(s) or licensor are credited and that the original publication in this journal is cited, in accordance with accepted academic practice. No use, distribution or reproduction is permitted which does not comply with these terms. 